Debate 



\title{
A psicologia do trabalho na FranÇa e a perspectiva DA CLÍNICA DA ATIVIDADE
}

Yves Clot ${ }^{\star}$

\begin{abstract}
APresentaÇão
Apresentamos, a seguir, a conferência proferida pelo professor Yves Clot, no dia 18 de setembro de 2007, durante evento realizado na Universidade Federal Fluminense, no Instituto de Ciências Humanas e Filosofia. O conferencista tratou da emergência da clínica da atividade, considerando a história da psicologia do trabalho na França. A tradução foi feita por Neide Ruffeill e Claudia Osório2. Agradecemos a Décio Rocha3 a revisão do texto final.
\end{abstract}

Palavras-chave: Psicologia do Trabalho; clínica da atividade; atividade; subjetividade.

\section{WORK PSYCHOLOGY IN FRANCE AND THE ACTIVITY CLINIC POINT OF VIEW}

\section{Presentation}

The text below is the conference given by Prof. Yves Clot on September 18, 2007. This conference was presented at the Fluminense Federal University, at the Human Sciences and Philosophy Institute. It focused on the appearance of activity clinic, in the field of work psychology in France. Neide Ruffeil and Claudia Osorio translated the conference from French to Portuguese. We thank Décio Rocha for the final revision.

Keywords: work psychology; activity clinic; activity; subjectivity.

\footnotetext{
^ Titular de psicologia do trabalho no CNAM (Conservatoire National des Arts et Métiers), diretor do CRTD (Centre de Recherche Travail et Développement).

E-mail: yves.clot@cnam.fr

${ }^{1}$ Psicóloga. Doutora em Psicologia Social pela Universidade do Estado do Rio de Janeiro, atualmente é professora titular adjunta na Universidade Federal Rural do Rio de Janeiro no Departamento de Educação e Sociedade.

${ }^{2}$ Psicóloga. Doutora em Saúde Pública pela Fundação Oswaldo Cruz. Atualmente é professor adjunto da Universidade Federal Fluminense.

${ }^{3}$ Doutor em Lingüística Aplicada e Estudos da Linguagem pela Pontifícia Universidade Católica de São Paulo. Atualmente é professor adjunto de Linguística e Francês da Universidade do Estado do Rio de Janeiro.
} 


\section{A ConferênCIA}

A conferência que eu previ fazer hoje é uma conferência cujo título é A psicologia do trabalho - a tradição francófona em psicologia do trabalho - e o que pode trazer a esse quadro aquilo que busco fazer hoje, a clínica da atividade.

Eu gostaria de dizer que ampliei um pouco a questão. Eu trato, evidentemente, da psicologia do trabalho e, mais largamente, abordo a questão da ergonomia, pois considero que a ergonomia faz parte da análise do trabalho, e mesmo da análise psicológica do trabalho. Em todo o caso, na França é assim. Portanto, tentarei dar um lugar, um lugar que para mim é importante, à ergonomia, nesta conferência.

Esta conferência tem como objetivo, se eu posso dizer assim, tentar expor as iniciativas e os problemas que encontraram três gerações de analistas do trabalho na França e no mundo francofônico. Tentarei traçar brevemente a história de três gerações de psicólogos do trabalho francofônicos, e demonstrar, do meu ponto de vista, modesto, o lugar que eu tento ocupar nessa história, o que faço do trabalho que foi feito por três gerações. Minha maneira de lê-la, compreendê-la, prolongá-la. Minha própria maneira de respeitar essa herança.

Evidentemente, todos os homens e mulheres dos quais vou falar são para mim objeto de um grande respeito, porque são eles que me permitiram introduzir-me no ofício que exerço atualmente; no fundo, quando eu faço a clínica da atividade é sempre pensando nos antigos, que nos deixaram uma herança que não podemos comprometer. Portanto, é com grande respeito que eu vou tentar traçar esse caminho da história dessas três gerações.

A primeira geração que inventou a análise do trabalho é a geração que viveu no começo do século passado, início do século XX, nos anos de 1900, 1910, antes da Grande Guerra de 1914 - 1918. É toda uma geração que, de certa maneira, precedeu, na França pelo menos, a chegada da Organização Científica do Trabalho, que é mais conhecida com o nome de OCT ou de taylorismo. A análise do trabalho francofônica, e mesmo o que já se chamava de Psicologia do Trabalho, precedeu a chegada do taylorismo nas fábricas, desde o começo do século XX, na França.

Esses primeiros psicólogos do trabalho têm diversos nomes, destacarei dois em especial, já que não poderei tratar de toda a história aqui, não tenho tempo para isso. O que me dá, particularmente, prazer é que entre eles há uma mulher, o que é muito raro em nossa disciplina. Essa mulher contribuiu muito, foi muito mais importante do que aparece na história oficial, eu gostaria de lhe render homenagem, essa mulher se chama Suzanne Pacaud.

O segundo grande psicólogo do trabalho, precursor, se podemos dizer assim, foi o chefe de Suzanne Pacaud. Evidentemente o chefe do laboratório era um homem, com quem ela trabalhou muito. Ele se chama Jean Maurice Lahy.

Esses dois psicólogos do trabalho, que começaram a trabalhar nos anos 1910, do século XX, inventaram o que podemos chamar de psicotécnica do trabalho. Tentarei dizer, em poucas palavras, em que essa psicotécnica era revolu- 
cionária para a época. Ela era revolucionária porque, vejam, eles eram psicólogos de laboratório, eram psicólogos "normais", fechados em laboratórios, mas, ao mesmo tempo, tinham preocupações sociais muito fortes, eram humanistas, pessoas que estavam preocupadas em posicionar o homem no centro do mecanismo de desenvolvimento econômico. Então eles eram humanistas. E esses psicólogos, que estavam fechados em laboratórios, decidiram que o melhor laboratório para compreender o homem, e em particular o comportamento humano, o melhor laboratório era, ainda, a indústria. A indústria em plena transformação, no início do século XX, com a Revolução Industrial, no momento em que milhões de camponeses chegavam às indústrias e se confrontavam com as condições de trabalho difíceis, multiplicando-se os acidentes, os problemas de saúde e, certamente, os problemas de qualificação. Portanto, foram psicólogos que decidiram sair do laboratório, para se situarem no interior das fábricas e aí compreender o comportamento do homem em situação.

Como diríamos hoje, a psicologia do trabalho é, de início, uma psicologia situada, uma psicologia da ação situada. O que é de alguma forma um paradoxo. A ação situada não foi inventada nos anos 1970 nos Estados Unidos. De certa maneira, ela existia no início do século XX, na França, com os psicólogos do trabalho.

E o que fizeram esses psicólogos, saídos do laboratório, nas fábricas?

Isso é muito interessante, eu não tenho tempo para desenvolver muito, mas eu gostaria de dizer duas coisas. A primeira é que eles foram, de início, sensíveis ao fato de que a atividade humana não é, jamais, conforme aquilo que foi previsto para ela, e o que, de uma certa forma, vamos reencontrar depois, o trabalho real, não é, jamais completamente, a projeção do trabalho prescrito. Eu diria mesmo que eles foram um pouco além disso... Eu tive a felicidade de encontrar recentemente, sob a pena de Suzanne Pacaud, a bela frase que cito: "O homem não se manifesta somente naquilo que ele faz, mas, frequentemente e, sobretudo, naquilo que ele não faz". Vejam que esses primeiros psicólogos do trabalho já haviam compreendido que toda a atividade humana não é diretamente observável. Eles haviam compreendido que, no fundo, o homem ultrapassa sempre a tarefa que lhe é confiada. Então, esses psicólogos do trabalho, humanistas, tomaram em toda a sua importância o fato que - como dirá Friedman mais tarde - "O homem é sempre maior do que a sua tarefa". E essa primeira experiência, que é verdadeiramente fundadora da psicotécnica do trabalho de língua francesa, se o podemos dizer, devemos associá-la a um segundo dado, sobre o qual eu vou insistir: que temos aí pessoas que empregaram métodos de observação do trabalho totalmente originais, um pouco particulares, e, literalmente, abandonados hoje. Pensavam que para compreender o trabalho de outrem seria necessário fazê-lo. Portanto, Suzanne Pacaud e Jean Maurice Lahy foram pessoas que trabalharam com condutores de trem, e também com telefonistas, assim como também com trabalhadores de diversos outros ofícios.

Cada vez eles usaram um método um tanto particular, que consistia em assumir o posto de trabalho e fazer um estágio de seis meses, no qual eles praticavam o ofício dos assalariados que eles observavam. Eles inventaram, também, 
métodos que foram em seguida, abandonados, mas que, pessoalmente, eu reencontrei fazendo a história. Infelizmente, é preciso fazer arqueologia para encontrar tudo isso - eles utilizaram métodos interessantes, chamados por Suzanne Pacaud de "auto-observação confrontada à observação de outros".

Os senhores compreenderão, ao final de minha exposição, o quanto isso pra mim é muito caro porque, de certa maneira, reencontrei preocupações que eu achava ter descoberto nos anos 1980. Ao final das contas temos de ser modestos e reconhecer que o que às vezes acreditamos ter inventado, foi muitas vezes precedido por iniciativas de outrem, ainda que tais iniciativas não tenham sido sustentadas em seguida.

Isso quer dizer o quê? Que Suzanne Pacaud ocupava, primeiramente, o posto de trabalho a ela ensinado e, em seguida, ela pedia às operadoras, em particular às telefonistas, que criticassem a sua própria atividade durante o trabalho. Dessa maneira, ela de certa maneira, tornou o trabalho visível. Evidentemente, ela não era muito boa telefonista, pois que não era seu ofício, portanto cometia erros. Como havia muitas coisas que ela não conseguia fazer, ela pedia a outra telefonista, ou profissional, para dizer o que não estava bem na sua atividade. Era o meio que ela havia encontrado, a janela de acesso que lhe permitia chegar a atividade pela crítica de sua própria atividade.

Isso ela refletia por volta de 1915-1920, na época da Primeira Guerra Mundial. No começo do século XX, eles faziam isso. A ideia era tentar apreender o que se denominava "aptidões" dos trabalhadores, o que hoje chamaríamos de "competências". Eles tentaram, de certo modo, descrever o trabalho por uma forma de observação centrada no próprio trabalho. Estamos longe de fazer análise do trabalho assim, eu não quero dizer que deva ser feito dessa forma, mas nós esquecemos que muitos o fizeram.

Infelizmente, - infelizmente! - essa psicotécnica do trabalho pegou um caminho errado, começou bem e terminou mal. Para aqueles que conhecem um pouco a história da análise do trabalho, mas não forçosamente, pode ser da psicotécnica, imagino que jamais tenham ouvido falar da psicotécnica da forma como acabo de descrever, o que é normal, porque a psicotécnica não é isso. A psicotécnica do trabalho se desviou, pode-se dizer que ela foi subvertida à psicotécnica da aptidão, ou seja, do teste. Tornou-se algo diverso, virou a adequação da pessoa em função do posto de trabalho.

Temos, então, uma trajetória da psicotécnica que começa pela análise do trabalho, que inventa a técnica da análise do trabalho, vem a ser, pouco a pouco, aquilo que ela será após a Segunda Guerra Mundial, um instrumento da gestão da mão-de-obra. Após uma crítica do taylorismo - porque isso começou assim, por uma crítica do taylorismo - a psicotécnica tornou-se, na França, após a Segunda Guerra Mundial, um dos instrumentos maiores de generalização do taylorismo. Portanto, essa é uma lição para jamais esquecer, começa-se pela inovação e podese terminar a serviço do sistema econômico no qual nós vivemos. 
Quero dizer que essa é uma reflexão que frequentemente faço sobre a minha própria atividade. Há muitos riscos na história quando se pretende inovar. A clínica do trabalho que nós tentamos fazer não está a salvo desse processo de desvio de seu curso.

Essa psicotécnica se perdeu de seu curso inicial. Por que ela se perdeu? Porque finalmente ela pensou que havia uma adequação, um cruzamento entre as aptidões passíveis de serem encontradas nos trabalhadores e a definição das necessidades do posto de trabalho; Pensar essa coincidência fez dela um instrumento de seleção, com um argumento democrático, pois, segundo esse argumento, era melhor selecionar as pessoas por suas aptidões do que pelas diferenças de origem social. Encontramos, assim, a noção de aptidão, a pedra filosofal da seleção feita de maneira justa. Portanto, a psicotécnica tornou-se um instrumento de seleção e ela acabou, como dizia Suzanne Pacaud, na "testomania".

Esta psicotécnica, que escolhi como exemplo da primeira geração, que termina mal, nos leva a fazer um diagnóstico fundamental. É necessário fazer um diagnóstico do porquê de não ter dado certo. Esse desvio ocorreu porque essa psicotécnica do trabalho é fundamentalmente positivista. Quer dizer, ela parte do princípio de que - segundo a fórmula de Auguste Comte, o pai do positivismo - a série que devemos seguir é a seguinte: saber para prever a fim de agir. A ação está no final, primeiro é preciso saber. A análise desses psicotécnicos pretendia, inicialmente, descrever e categorizar a atividade, para, em seguida, favorecer o processo de seleção. Portanto, primeiro saber, para em seguida poder prever, para, depois de prever, agir. Aqueles que agem são sempre os conceptores, organizadores, recrutadores. Os selecionados não são sujeitos da ação, são objeto da seleção. E, paradoxalmente, esta psicotécnica que colocou o saber em posição dominante é uma psicologia do trabalho que se perdeu porque ela se voltou contra os trabalhadores, ainda que tenha partido no começo de uma psicologia do trabalhador. Essa foi a primeira geração.

A segunda geração, evidentemente, se volta contra esta deriva da psicotécnica. Ela quis retomar o problema do zero, ela criticou a psicotécnica, e penso que fez bem. A psicotécnica que ela criticou é a psicotécnica do teste, a psicotécnica da seleção, a psicotécnica tayloriana. E a crítica a Taylor é verdadeiramente necessária. Infelizmente, como é freqüente na história das ciências, ao criticar, esquecemos o início e, de certa maneira, talvez respeitemos de modo insuficiente o trabalho inicial dos psicotécnicos.

Eu vou tentar, inicialmente, descrever essa crítica da psicotécnica pela geração seguinte. Na geração seguinte há três grandes correntes de crítica à psicotécnica. Correntes que a gente conhece muito bem, correntes que a gente não conhece bem.

Abordarei três frentes científicas de combate que se opõem à psicotécnica. A primeira, depois da Segunda Guerra Mundial, no apogeu da taylorização na França, no momento mesmo em que a psicotécnica se tornou um grande perigo para quem quer fazer psicologia, quando vemos a pessoa sujeita aos resultados de 
exames, e o desaparecimento da análise do trabalho. A psicotécnica fez desaparecer a análise do trabalho, a situação de trabalho desapareceu, é normal que haja uma crítica da primeira geração.

Há três críticas fundamentais, três correntes fundamentais. Eu chamaria a psicologia cognitiva do trabalho em primeiro lugar, na qual apareceram grandes nomes da psicologia do trabalho francesa, um dos quais está aindo vivo, eu vou escrever esses nomes: Faverge e, em seguida, Leplat, que tem hoje 88 anos, e quem eu ainda vejo regularmente, no prédio da Gay de Lussac ${ }^{4}$ onde eu trabalho. A psicologia cognitiva do trabalho é uma psicologia extremamente importante. Eu mesmo já a critiquei, mas ela é extremamente importante. Ela é, antes de tudo, uma crítica à psicotécnica. Faverge faz duras críticas contra a psicotécnica, por volta de 1955, que é o ponto de partida da análise do trabalho francófona; tem um livro intitulado $A$ análise do trabalho no qual há muitas coisas. Faverge enfrenta os psicotécnicos do trabalho dizendo que o mundo não funciona assim, que as aptidões não estão na cabeça do sujeito, onde se tem a pretensão de buscá-las com testes. As aptidões estão na situação mesma do trabalho. É necessário voltar à situação do trabalho É necessário romper a coincidência entre as aptidões e a situação, é necessário voltar à situação, porque é na situação que vamos encontrar a raiz dos recursos do desenvolvimento das aptidões. As aptidões não estão de início no sujeito, mas estão nos problemas postos pela situação. É o que faz com que, quando se emprega alguém, diz Faverge, quando se emprega alguém em um posto de trabalho, não se pode absolutamente prever como ele vai trabalhar, porque esse sujeito na situação vai ser obrigado a reinventar as aptidões que ele não tem, ele vai encontrar nas situações razões para criar uma nova competência, novas aptidões, como se dizia à época.

Portanto, diz Faverge, a análise do trabalho entra com as aptidões, mas ela deve retornar à situação, pois é na situação que se encontram as raízes da competência. Dá-se, neste momento, a invenção da famosa distinção, no plano conceitual, entre a "tarefa" e "atividade". A "tarefa" e a "atividade". Há uma definição que eu vou criticar, mas que é uma definição fundadora.

A tarefa é o que está por se fazer; como esses psicólogos, Faverge e Leplat, são gente de campo (empírico) eles entenderam que entre o que há a ser feito e aquilo que se faz realmente para chegar aquilo que se quer fazer, há um mundo. É necessário pensar a atividade. Nós estamos aqui em 1955, é a primeira vez que se faz essa distinção.

Mas vamos mais longe nessa psicologia cognitiva do trabalho. Vamos mesmo um pouco além, porque vamos dizer que é necessário nos colocarmos no ponto de vista do sujeito, e o sujeito não é estoque de aptidões, o sujeito é um sistema de tratamento das informações, portanto vemos bem a inspiração cognitiva das coisas. É uma das primeiras vezes em que se usa a metáfora do computador para pensar o sujeito humano, o sujeito humano como um sistema de captar informações.

\footnotetext{
${ }^{4}$ Refere-se ao prédio onde se localiza o Conservatoire National des Arts et Métiers (CNAM), em Paris.
} 
Isso é muito interessante porque, de certa maneira, como diria, isso identifica o sujeito como sendo a fonte de uma espécie de criação. É um sistema de tratamento da informação, não há somente aptidão, há sujeito. Isso é muito importante e, ao mesmo tempo, é limitado. Esta ideia de considerar o ser humano como um sistema de tratamento da informação, com a metáfora da informática que está por trás disso, traz um efeito, um inconveniente maior: é o de reduzir o sujeito a um instrumento de conhecimento. Esse é um sujeito epistêmico, intelectual. É trazer o sujeito a um sujeito intelectual, é um sujeito desencarnado, poderia mesmo dizer que essa psicologia cognitiva do trabalho desenvolve uma concepção desencarnada do sujeito. É um sujeito sem corpo. Um sujeito que não se coloca problemas de saúde, por exemplo, um sujeito que não é afetado pelas situações, mas é um sujeito que trata as situações.

Bom, nessa crítica à psicotécnica, esse sujeito é um sujeito sobretudo desencarnado, é um sujeito que é quase um conjunto de programas. É um problema maior. E, nessa mesma época, se desenvolve a segunda grande corrente de crítica à psicotécnica, essa certamente os senhores conhecem, alguns talvez até muito melhor que eu, é a ergonomia.

Em 1955, quando Faverge publica Análise do Trabalho, é o momento em que Alan Wisner está organizando, por suas iniciativas sistemáticas, a ergonomia francófona. De passagem, eu indico que isso acontecia no mesmo imóvel do início do século - o Gay de Lussac - onde me encontro ainda hoje, que se pode chamar a Meca da análise do trabalho francofônica.

Alan Wisner não é parte da psicologia cognitiva. Alan Wisner é um médico. O problema de Wisner é, de início, a saúde. É isso que o fez ir adiante, podese dizer. Sua preocupação é ver os trabalhadores mal tratados em sua situação de trabalho e, sobretudo, pensar como fazer de outra forma, já que não há razão para suportar o insuportável.

Seu compromisso, de posição social extremamente clara, o engaja no ponto de vista do sujeito, mas o sujeito que Wisner tem em mente é um trabalhador, não é simplesmente um sujeito epistêmico. É um sujeito social, em situação de trabalho real, que sofre também sua condição social.

Wisner tem um engajamento militante, social, do ponto de vista do sujeito que é um trabalhador. Ele coloca o que? Ele coloca o problema da saúde. Em Alan Wisner há um corpo, à diferença da psicologia cognitiva do trabalho, que é a primeira corrente. Evidentemente, Wisner foi um inimigo jurado da psicotécnica e não suporta que se reduza o sujeito a um estoque de aptidões, mas pensa que as aptidões do trabalhador dependem da condição que se lhe oferece e da situação de trabalho que ele tem. Portanto, sua ideia é que, se queremos modificar as aptidões dos trabalhadores, é necessário transformar a situação. É a transformação da situação que coloca em curso o desenvolvimento das aptidões. Quando queremos nos ocupar da aptidão, não devemos julgar o sujeito, devemos observar a situação que produz as aptidões. 
Para Wisner, o trabalho não se faz consumindo as aptidões. No trabalho se mobilizam as aptidões. O trabalho fabrica aptidões, não faz somente utilizar aptidões.

Wisner vai retomar essa dupla conceitual que nos é muito cara a todos. E enquanto a psicologia cognitiva do trabalho distingue "tarefa" e "atividade", Wisner vai dar preferência a utilizar "trabalho prescrito" e "trabalho real". Porque entre "trabalho prescrito" e "tarefa" há uma diferença. A tarefa, de certa maneira, é uma coisa relativamente independente da condição social

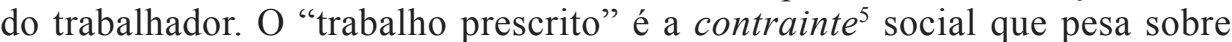
o trabalho humano. O "trabalho prescrito" é o peso da prescrição, o peso da contrainte, o peso da astrainte. É também a diferença social entre aqueles que trabalham embaixo e aqueles que concebem o trabalho dos outros. Por que Wisner vai então falar de trabalho prescrito e real? Ele vai falar de trabalho real porque, para Wisner, o trabalho real não é simplesmente a atividade cognitiva. O trabalho real para Wisner é a vida. Isso quer dizer, como fazer em situação de forte contrainte para continuar vivendo, mas não somente continuar vivendo, mas para encontrar na situação novos meios de vida e ter prazer no trabalho? Como se pode finalmente agir na situação?

Wisner se preocupa com a saúde no trabalho e poderia se dizer que, para Wisner - isso é discutível, mas eu sou obrigado a ir rápido - para Wisner há uma coincidência entre "atividade" e "saúde". "Saúde" e "atividade" são sinônimos, porque "atividade" para Wisner é se sentir ativo. Não é simplesmente fazer alguma coisa, é se sentir ativo e isso não é a mesma coisa. Sentir-se ativo é sentir-se sujeito em um meio, sujeito de uma organização, e não somente objeto de uma organização. Portanto, sentir-se ativo é precisamente diminuir o distanciamento entre isso que é necessário fazer, isso que está previsto, que te é exigido pela prescrição, e aquilo que é mais que a realidade, na qual é necessário inventar meios de fazer as coisas, apesar de tudo.

Em Wisner, um pouco da força desse paradigma da Ergonomia francófona é ao fundo, de início, a separação entre "prescrito" e "real" e, em seguida, é fazer do "real" a fonte da criação, da engenhosidade, da atividade e da curiosidade mesma dos trabalhadores. Há uma admiração, portanto, em Wisner, pela capacidade dos trabalhadores de transformar a situação mal vivida, em situação que ele domina.

Há uma admiração da engenhosidade dos trabalhadores em situação real. Isso não é a mesma coisa que a psicologia cognitiva do trabalho. Isso se passa na mesma época, eles discutem juntos, eles brigam, e é assim que a ciência avança. Mesmo se eles brigam nos corredores, e trata-se do mesmo prédio, eles trabalham juntos, eles se confrontam. Isso não é a mesma coisa. De um lado é tarefa-atividade; e de outro, é trabalho real - trabalho prescrito. De um lado há o social, o corpo; e de outro, sobretudo, o intelecto e a cognição. Para Wisner, nunca o sujeito

\footnotetext{
${ }^{5}$ Para o vocábulo contrainte, categoria analítica utilizada pela ergonomia francofônica, não se encontrou qualquer tradução satisfatória em português; pode-se traduzir por coerção. A forma mais frequentemente utilizada é "exigência", o que é limitado, tal a riqueza do que aponta a expressão francesa. Aqui foi mantida a expressão na língua original.
} 
humano pode ser comparado a um sistema de computador. Ele não é um sistema de tratamento da informação. Ele é um sujeito social, vivo, ativo, que trata de resolver situações impossíveis nas quais ele é colocado.

Portanto, vê-se que essa segunda corrente, essa segunda geração, nos deixa uma espécie de visão positiva do trabalho humano. O trabalho é positivo, é um lugar de engenhosidade, de invenção, de criação. É, certamente, também um lugar de sofrimento, e isso Wisner nunca ignorou, mas é um lugar onde não se fica passivo, é um lugar de atividade, de saúde, de criação de um meio, não somente de ausência de doença.

Não temos tempo, mas poderíamos comparar a concepção de atividade de Wisner com a concepção de saúde de Canguilhem que penso estarem próximas, embora o próprio Wisner não tenha apontado essa proximidade.

Bom, enfim, finalizo essa segunda corrente, essa segunda geração. Essa segunda corrente nos deixa uma espécie de visão positiva do trabalho humano, poderia mesmo dizer esse encantamento com o trabalho. Alan Wisner obteve sucesso em transmitir essa herança. Há necessidade, quando se vai aos lugares de trabalho, de poder se maravilhar com o que as pessoas são capazes de fazer, apesar de tudo. Há alguma coisa de maravilhoso nisso. Wisner era apaixonado por essa atividade operária, mas não somente operária, era apaixonado por essa atividade.

Então, sabemos muito bem, e isso vai me permitir passar à terceira corrente, sabemos muito bem que, com Wisner, há uma inteligência da situação, há uma sensibilidade, há a invenção de uma prática de transformação, há uma certa relação com o mundo do trabalho. Há, portanto, uma criatividade prática na intervenção, que é sua herança principal. Há, mesmo, uma tomada de partido, uma tomada de partido pelo trabalho, não pelos trabalhadores, porque ele estava atento em não misturar tudo, o sindicalismo e a análise do trabalho. Mas uma tomada de partido pelo trabalho, porque o trabalho é qualquer coisa que faz transpor o fosso entre o que é exigido e a realidade da vida, é a inteligência do trabalho.

Wisner era, sobretudo, um grande prático da análise do trabalho. É um artista da análise do trabalho. Ele definiu muitas vezes a ergonomia como uma arte, é um pensamento forte, e ele definiu também o trabalho do engenheiro como uma arte. Eu não tenho tempo de me estender sobre isso, mas era a ergonomia como uma arte.

Eu creio que o limite da herança de Allan Wisner - e eu digo isso com muita humildade, e também porque falei muito sobre isso com ele - o limite é que a conceitualização da atividade, e mesmo da intervenção, não estavam no centro das suas preocupações. Eu penso que isso é extremamente legítimo porque era necessário criar a ruptura na análise do trabalho, e, portanto, ele era sobretudo um prático que rompeu com o modelo dominante de análise do trabalho, mesmo em relação à psicologia cognitiva. 
Vejam bem que a psicologia cognitiva que faziam Faverge e Leplat era muito menos custosa, havia muito menos trabalho de campo e muito mais laboratório, o que depois se tornou, o que chamamos hoje de psicologia ergonômica. A psicologia ergonômica de hoje é a psicologia cognitiva que vem de Faverge e Leplat. E que nos deu a engenharia cognitiva de hoje.

Wisner nos deixa, isso é talvez finalmente sua honra, ele nos deixa um gosto de ação, ele nos deixa uma vacina contra o dogmatismo, por dizer que agir é justamente partir do campo e não buscar no campo aquilo que a ciência busca, não é fazer do campo um meio de fazer ciência. Para Wisner, o campo é central, e vamos ao campo para resolver os problemas e utilizamos a ciência para resolver os problemas.

A psicologia cognitiva, vejam, é o inverso, ela se serve do campo como meio, enquanto a ergonomia se serve da ciência como meio para resolver os problemas do campo.

Em essência, essa ruptura - que é uma ruptura do positivismo dominante que matou a psicotécnica, por isso Wisner é tão importante - nos deixa como herança, posso dizer que uma herança a discutir, pois se os senhores olharem as conceitualizações da atividade por Wisner elas são, a uma só vez, magníficas e complexas. Por trás disso há muito trabalho para compreender isso que ele fez e como ele utilizou as conceituações da atividade e, pode-se dizer, da vida, sem contudo ter tempo ou talvez mesmo o gosto pelo desenvolvimento dos conceitos, ele é um homem de ação. Ele era um médico preocupado em desenvolver a saúde em situação real.

A herança teórica, em termos de corpo conceitual da ergonomia francófona, que Wisner nos deixou é uma herança que nos faz ainda trabalhar até hoje, porque não parou, é aberta. Ele é complicado e nos faz pensar. Portanto, devemos agradecer a Alan Wisner por não ter dito tudo. Sua herança é precisamente que a última palavra jamais foi dita. Nós sabemos o que Wisner nos deixou como herança, o fato de que nós temos a responsabilidade de prolongar essa obra e de a reinventar porque nós a respeitamos.

Assim, chego à terceira corrente. Na mesma época, durante os anos 1950 , se passam coisas fora do Gay Lussac, o que é bom, as coisas se diversificam um pouco. Há psiquiatras que se colocam nesse trabalho. Há trabalhadores, em particular condutores de trem, mas também trabalhadores dos correios, num momento em que o taylorismo fica extremamente duro de suportar. Há coletivos de trabalhadores que vão se dirigir a um certo tipo de psiquiatras um pouco bizarros. Psiquiatras que estão nos hospitais psiquiátricos, mas que participaram durante a guerra da resistência, fizeram grandes experiências muito importantes na resistência - durante a resistência e durante a Guerra - e que saíram da guerra, nos anos 1950, na França, com um desejo de fazer uma psiquiatria social. E há trabalhadores que se dirigem a esse psiquiatra. Esse psiquiatra se chama, em particular, Louis Le Guillant. Louis Le Guillant é o inventor da psicopatologia do trabalho que é uma contribuição muito importante para a análise do trabalho francófona, e mesmo para a psicologia do trabalho propriamente dita. É um psiquiatra social, 
pode-se dizer, que fez - junto com outros psiquiatras, Tosquelles em particular - durante a Guerra, uma experiência interessante. Eles dirigiam hospitais psiquiátricos, hospitais psiquiátricos muito grandes e durante a guerra se encontraram confrontados a uma situação muito particular.

Os senhores podem imaginar, durante a guerra - quando mesmo aqueles que não eram loucos, pessoas como nós, tinham dificuldades para viver, mesmo para se alimentar - a situação dos hospitais psiquiátricos. Acreditava-se que aqueles que estavam dentro dos hospitais psiquiátricos não recebiam muita atenção. Eram os grandes esquecidos da guerra.

Em particular, esses psiquiatras se encontraram em uma situação de urgência quando os bombardeios da Alemanha sobre a França se desenvolveram. Eles decidiram, para salvar os loucos dos hospitais psiquiátricos - em quatro ou cinco grandes hospitais franceses - abrir as portas do hospital. Em lugar de ver os doentes sofrerem com as bombas, eles deram uma chance a esses doentes. Eles liberaram os loucos, como se dizia na época, durante o bombardeio. É, sem dúvida, uma experiência extremamente importante, porque esses loucos, como se diz correntemente, se viraram bem. Eles viveram os mesmos dramas que os outros, e, de certa forma, se encontraram reintroduzidos na vida normal. Eles viveram as dificuldades coletivas da Guerra e da resistência francesa, com os outros, no campo. Vejam, portanto, uma situação diferente, os loucos estão nas ruas, no campo.

A experiência que eles fizeram foi a liberação após a Guerra. Muitos desses internos - considerados como definitivamente condenados, que se acreditavam acabados - não era útil reinterná-los. Haviam encontrado a saúde nas lutas coletivas, dividindo com os outros os dramas da história coletiva e tinham refeito a saúde, pode-se dizer, ainda que não completamente já que eles estavam muito degradados, mas em todo caso, podiam viver fora dos hospitais psiquiátricos fechados. Para os psiquiatras isso já era uma experiência considerável.

Como, quando a vida social era um pouco extraordinária, - nessa época não era uma vida normal, era uma vida muito diferente, era uma vida sui generis, era uma vida de resistência coletiva - como faziam esses sujeitos, tidos como incuráveis, que se encontravam em situação de reinventar sua própria existência, de reencontrar sua vitalidade psíquica, em uma situação em que não havia cuidados psiquiátricos? Eles só podiam se beneficiar da atividade dos outros.

Portanto, esses psiquiatras refletiram muito, eles refletiram muito, no que foi chamado em seguida de movimento da psiquiatria institucional, e mesmo no movimento da antipsiquiatria.

Le Guillant, tendo conhecido experiências similares, estava muito atento à função do trabalho, pode-se dizer à função psicológica do trabalho, a função psíquica do trabalho. Portanto, quando os trabalhadores nos anos 1950, verdadeiramente sobrecarregados pela taylorização, vinham solicitar-lhe um suporte na crítica à condição de existência no trabalho, Le Guillant estava muito atento aos trabalhadores e é por isso que ele foi o iniciador da psicopatologia do trabalho. 
Essa psicopatologia do trabalho, eu vou caracterizá-la muito rapidamente, por duas características. A primeira é que, num sentido quase contrário ao trabalho de Wisner, esses psiquiatras acham que o trabalho não é positivo, não é um lugar de criação, não é um lugar de desenvolvimento do sujeito, é um lugar dramático para o sujeito, é o lugar onde o sujeito se perde.

Dito de outra forma, esses primeiros psicopatologistas do trabalho introduzem o que podemos chamar a dimensão negativa do trabalho, o trabalho não é apenas positivo, é negativo, o trabalho faz mal, torna as pessoas doentes e loucas. E quando esses psiquiatras, que fizeram a experiência da guerra, entram em contato com as situações de trabalho à época das grandes fábricas que se desenvolvem, nas quais são contratados milhares de operários em situações de grande submetimento profissional, esses psiquiatras vão inventar - essa é a primeira inovação de Le Guillant - a ideia, segundo a qual, há uma síndrome subjetiva da fadiga nervosa, eles são especialistas da fadiga nervosa, que mostra que esses sujeitos estão sobrecarregados, eles estão profundamente feridos pelas condições de trabalho.

Isso se faz em paralelo com a Ergonomia, ao mesmo tempo, se faz também em paralelo com a psicologia cognitiva do trabalho. É a mesma época, mas não é a mesma coisa. Esses psiquiatras - Le Guillant, em particular - vão começar a se interessar pela maneira pela qual os trabalhadores chegam a suportar essas situações insuportáveis.

Le Guillant foi o primeiro, eu penso, a inventar, mesmo se ele não a conceituou, a ideia de sistema de defesa profissional. Foi ele que escreveu um dia, essa frase emprestada de Simone Weil, a filósofa, "os trabalhadores são muitas vezes obrigados a não pensar para não sofrer", agir sem pensar para não sofrer. Isso é muito interessante, porque Le Guillant identifica já nessa situação o que chamaremos depois sistemas de defesa. As vezes é necessário fechar os olhos, esquecer, não refletir ao que se passa conosco para poder suportar essa situação. De certa forma se anestesiar, a anestesia psíquica como meio de suportar sua condição.

Vejam em torno do que Guillant trabalha, vejam que isso está muito longe da ergonomia, mas é muito importante porque Le Guillant sublinha que o trabalho não é simplesmente uma atividade, enquanto que em Wisner há essa espécie de invenção da atividade, Le Guillant diz não, o trabalho não é simplesmente uma atividade, o trabalho é uma condição, trata-se de uma condição social. Quando se é operário de usina ou telefonista, não estamos somente agindo para realizar uma tarefa. Estamos submetidos a uma condição social na qual estamos colocados e na qual há alienação. Podemos dizer a psicopatologia do trabalho descobre a clínica da alienação.

Com Le Guillant há uma segunda ideia muito forte, é mais do que uma ideia, é verdadeiramente uma noção, a noção de ressentimento. Ele fez um trabalho - cuja leitura aconselho, que é muito fácil porque está traduzido em português, graças aos esforços de Beth Lima - que é um estudo de referência, é um grande clássico da análise do trabalho, um texto que se chama "As empregadas 
domésticas"6. Evidentemente, os senhores me diriam, aí estamos longe da fábrica, claro, estamos longe da fábrica, mas quando vemos os textos que Le Guillant escreveu sobre a relação entre as empregadas e suas patroas, no trabalho doméstico - sobretudo que essas empregadas eram mulheres - encontramos muitas razões, muitos instrumentos para compreender o trabalho de serviço, que nós encontramos hoje. Le Guillant trabalhando sobre a questão das domésticas, trabalha sobre um serviço, trabalha sobre a atividade profissional em que o objeto do trabalho é alguém, é um sujeito, é o outro.

O estudo de Le Guillant antecipa os estudos de psicopatologia do trabalho contemporâneos que são centrados sobre o serviço. Ele vai trabalhar sobre a servidão. O problema da servidão no trabalho das empregadas domésticas. Ele mostra como é um trabalho impossível ser empregada doméstica. Como ser empregada doméstica só pode levar a adoecer, salvo se tiver uma saúde excepcional, o que não é para todo mundo.

Isso leva a adoecer por quê? Porque, de certa maneira, entra-se no espaço doméstico privado desse patrão, ela se identifica com esse patrão, gostaria de ser como ele e, ao mesmo tempo, ela não é mais que uma coisa, ela é mesmo transparente para esse patrão. Como diz Le Guillant, a empregada para o patrão não é um sujeito, não é uma pessoa, é um instrumento. E portanto, ele analisa com muita fineza a relação de alienação entre a empregada doméstica e seus empregadores. Ele mostra como as domésticas ruminam sua alienação, o ressentimento da raiva e do ciúme em relação ao patrão.

E dois, há uma identificação, mas uma identificação impossível, já que socialmente impossível; em geral ela tem raiva do outro e raiva de si. Então há um crime passional, em particular das irmãs Papin, que não pode ser explicado senão por aí. Le Guillant fez um grande texto sobre isso, que assinala o ressentimento, quer dizer, o re-sentimento - o sentimento sobre sentimentos. É esse ressentimento que no fundo está na origem da doença mental.

Vejamos aqui uma psicopatologia do trabalho que se ocupa do corpo, que se ocupa das perturbações do espírito, que avança nas questões da saúde mental e que introduz na análise do trabalho o drama humano da análise do trabalho.

Eu chego então a uma terceira geração, eis o problema. É complicado porque temos de lidar com tudo isso. Não podemos, em minha opinião, fazer triagem na herança. É necessário fazer um tratamento de conjunto dessa herança, infelizmente. Então eu vou tentar insistir sobre as diferenças, eu vou tentar comparar a ergonomia e a psicopatologia do trabalho.

A ergonomia é a atividade, com toda certeza. A psicopatologia do trabalho é a subjetividade, é a subjetividade alienada, é a subjetividade impossível. É a impossibilidade de produzir a sua subjetividade no trabalho. Vejam, atividade e subjetividade, em primeiro lugar.

${ }^{6} \mathrm{O}$ estudo clássico sobre as empregadas domésticas, realizado por Louis Le Guillant, publicado em 1963, foi traduzido para o português sob o título "O caso das irmãs Papin" e publicado no livro Escritos de Louis Le Guillant: da ergoterapia à psicopatologia do trabalho. Petrópolis, RJ: Vozes, 2006. 
Em segundo lugar, a ergonomia é a observação, a observação em situação de trabalho. A grande invenção da ergonomia é esse trabalho minucioso, meticuloso, obsessivo. Frequentemente os ergonomistas dizem - nós somos míopes - porque eles não conseguem olhar de longe, eles passam seu tempo olhando de perto. A ergonomia é a invenção da observação do trabalho como método cardinal da análise do trabalho.

A psicopatologia do trabalho não pratica nenhuma observação. A psicopatologia do trabalho é a escuta, é a palavra, é o diálogo, é a troca. Portanto, poderia dizer, sendo esquemático, a ergonomia é a operação do trabalho em situação real e a ergonomia não se interessa inicialmente pela palavra. Os psicopatologistas do trabalho, ao contrário, se interessam somente pela palavra. Eles dizem mesmo que não é necessário fazer observação. Quando olhamos o trabalho de Le Guillant não lhe vem a ideia de entrar em uma indústria e nas situações de trabalho. O que ele faz é falar com seus pacientes e encontrar nas palavras contorcidas que lhe chegam a significação que vai poder interpretar.

Temos aí duas diferenças. De um lado, a atividade e, de outro, a palavra. Portanto, em resumo, atividade de um lado e subjetividade, de outro. Observação em situação e escuta, do outro lado.

É nesse ponto que pretendo definir, atendendo ao convite que me foi feito, definir minha própria contribuição ao trabalho da terceira geração. Mas pretendo fazê-lo com muita modéstia porque a terceira geração é numerosa, eu não sou a terceira geração, eu faço parte dela. Eu ocupo uma cadeira de psicologia do trabalho, eu já falei, mas não estou só, na terceira geração. Há os ergonomistas que são extremamente numerosos, tão numerosos que eu não posso citá-los. Há um que faz uma espécie de transição que eu não falei, que é Naville, que é importante. Hoje há Falzon que não é a mesma coisa que Wisner. Mas eu não posso listá-los.

Na tradição da psicopatologia do trabalho, que inventou a psicodinâmica do trabalho, há Cristophe Dejours, que também trabalha no mesmo prédio, e há mais pessoas na terceira geração, que são vários colegas de trabalho com quem eu penso que deveríamos debater, preferencialmente. Penso em Yves Schwartz que inventou a ergologia que os senhores conhecem também, a quem eu devo muito pois foi lá que eu me formei. Há um mundo de gente na terceira geração.

Bem, os senhores certamente sabem que eu não falo me elegendo um representante dessa terceira geração. Eu vou fazer apenas uma coisa: falar de como eu trato de produzir um caminho nesta herança, como eu tento me apropriar dela, procurando respeitá-la, o que quer dizer fazê-la viver. Evidentemente, a análise do trabalho continuará viva depois de nós, a última palavra não será jamais dita, depois que eu falar, é o que eu espero. Poderemos ainda dizer outras coisas e, sobretudo, eventualmente criticar o que vou dizer, assim eu posso aprender alguma coisa. E ainda uma outra coisa, para deixar tudo bem claro: a terceira geração não está aqui representada na minha pessoa. Eu faço parte dela e trato de ocupar a minha parte. 
Então a clínica da atividade é uma espécie de ruminação, como as domésticas de Le Guillant, eu rumino, eu repito. Eu digo que temos de compreender essa história e fazer alguma coisa dessa história que nos é comum, com todos os fantasmas que estão lá atrás.

Essa história se constitui em dois problemas. A concepção da ação em situação, em particular, o problema do método da ação, como agir para transformar o trabalho, porque o que faz a força dessa tradição francófona do trabalho é que ela quer mudar alguma coisa no trabalho, ela quer transformar, é o que nos une nessa terceira geração. Portanto, há um problema de concepção de ação, primeiro problema.

Em seguida, há um segundo problema que é a conceituação: a atividade e a subjetividade - é o quê?

Lógico, essa herança é considerável, ela às vezes intimida. No meu trabalho simplesmente quis pôr a minha pedra, a minha contribuição à conceituação da atividade e da subjetividade. Fazer minha parte neste trabalho comum que todos devemos fazer e tratar de ser fiel a essa herança.

Então eu vou tratar dessas duas questões muito rapidamente. A primeira é a questão dos métodos da ação. Na questão dos métodos eu gostaria logo de me referir a alguém que conta muito para mim e eu ainda não evoquei até agora, que está muito longe da análise do trabalho, mas por outro lado, está muito próximo. Que participou com Le Guillant dessas experiências dos hospitais psiquiátricos da guerra, que é, em seguida, o fundador do que chamamos de psicoterapia institucional, da corrente da psicoterapia institucional. Eu vou falar de François Tosquelles.

Tosquelles é um psiquiatra da mesma geração que Le Guillant, que conheceu a mesma situação que ele, que também foi um dos libertadores dos hospitais psiquiátricos e que também constatou até que ponto os doentes melhoravam quando confrontados com as situações normais da vida, e como os dramas compartilhados podiam propiciar a saúde mental. Ele é o inventor da ergoterapia. A ergoterapia, como sem dúvida os senhores sabem, é a tentativa, difícil, que não conheceu somente sucesso, é a tentativa difícil de fazer trabalhar os doentes nos hospitais psiquiátricos. Fazê-los trabalhar para ajudá-los a encontrar de novo a sua saúde. A ergoterapia é, portanto tentar usar, em psiquiatria, o trabalho como terapia, é a tentativa de olhar o trabalho como uma terapia. E Tosquelles é aquele que foi mais longe nessa matéria, mas ele o fez de uma maneira que é extremamente interessante.

Gostaria de fazer uma pequena citação de Tosquelles. Vou ler a citação. Em Tosquelles há uma definição de ergoterapia que é realmente genial, na minha opinião, porque ela nos ensina muito sobre a estratégia de ação em meio profissional. Há uma definição de ergoterapia como um fazer as pessoas trabalharem para tratá-los e Tosquelles nos diz que não é isso, não é isso a ergoterapia. O que é a ergoterapia para Tosquelles? 
"Não se trata de fazer os doentes trabalharem, para diminuir tal ou qual sintoma. Trata-se de fazer trabalhar os doentes e o pessoal que os cuida, para cuidar (soigner) da instituição".

Observem a inversão. Trata-se de fazer trabalhar o doente e o pessoal que os trata, para cuidar de quem? Para cuidar da instituição. "Para que a instituição e o pessoal de saúde captem no vivo - notem a expressão aqui - captem no vivo que os doentes são seres humanos sempre responsáveis por aquilo que fazem, o que só pode ser colocado em evidência na condição de fazer alguma coisa".

Vejam, se eu retomar essa frase e transplantá-la para a análise do trabalho, isso vai nos dar coisas muito interessantes do ponto de vista da ação. Isso significa que não se trata, em matéria de análise do trabalho, de cuidar ${ }^{7}$ do trabalhador, trata-se de, no método de ação, fazer trabalhar os trabalhadores para cuidarem do trabalho.

Não cuidar das pessoas, mas cuidar do trabalho. Quando digo cuidar do trabalho, em francês, tem um duplo sentido: transformar o trabalho, mas também, em francês, fazer um bom trabalho, é a qualidade do trabalho bem feito que é uma fonte de saúde. E, poderíamos dizer, para que a organização do trabalho apreenda no vivo ${ }^{8}$ que os trabalhadores são seres humanos responsáveis por aquilo que fazem, o que não é fácil de ser colocado em evidência e é essa a ideia, fazer com que a organização leve em conta que os trabalhadores são seres humanos responsáveis por aquilo que fazem. Para que eles apreendam isso em toda sua importância é necessário fabricar métodos que mostrem isso, fabricar métodos que mostrem que os trabalhadores são capazes de transformar a situação de trabalho.

De modo que cuidar do trabalho é transformar a organização do trabalho. Essa é uma forma de abordagem de ação. Criar situações e encontrar técnicas nas quais se transformem os trabalhadores em sujeitos da situação, fazendo-os protagonistas da transformação. Eles é que são os autores da transformação e não os especialistas.

Em certo sentido, não tenho tempo de desenvolver, mas vocês podem ver o quanto essa concepção de ação retoma o que fez Ivar Oddone à Itália, nos anos 1960. Após o Outono Quente, ele se apoiou nas iniciativas dos Conselhos de Usina, para transformar a psicologia do trabalho e transformar a questão da saúde no trabalho. O que Ivar Oddone fez não foi uma nova psicologia do trabalho, mas sim uma nova maneira de fazer psicologia do trabalho, colocando os trabalhadores como protagonistas desta psicologia dos trabalhadores, pode se dizer.

Tosquelles e Oddone, - perdoem-me pela expressão - estão no mesmo combate. São dois inspiradores da clínica da atividade, do ponto de vista da ação. Como podemos fazer na organização do trabalho, não para dizer o que seria necessário dizer para os trabalhadores, produzindo conhecimento sobre sua atividade, mas como fazer para que os trabalhadores com quem nós trabalhamos, façam a demonstração no vivo, como diz Tosquelles, que são capazes

\footnotetext{
${ }^{7}$ Soigner le travailleur e, a seguir, soigner le travail

${ }^{8}$ Sur Le vif
} 
de transformar a situação. Eles são capazes. Fazem a demonstração de que são capazes. Isso é um ato transformador profundo na história da análise do trabalho. Evidentemente é o contrário do positivismo.

Significa dizer que primeiro agimos, junto com os trabalhadores, e que, se não, agimos muito mal - não se pode tudo prever - temos a chance de apreender alguma coisa, mas apreender ao final. Não se busca, junto aos trabalhadores, confirmar a ciência. Isso não quer dizer que não se faça ciência, afinal é o nosso trabalho, mas voltaremos a isso adiante.

Nessa ação há um problema técnico particular que eu gostaria de tratar-que é muito caro aos ergonomistas, que é muito caro para mim também, que faço parte dessa família - que é a questão da observação. Como discutir o problema da observação se colocamos o problema da ação como acabei de colocar? A observação psicológica na clínica da atividade não é a mesma observação que a observação ergonômica. Para me fazer compreender eu vou fazer outra citação. Essa citação vem de um grande psicólogo francês que talvez vocês conheçam também, que é uma referência muito forte, que é Henry Wallon. Henry Wallon não fez psicologia do trabalho e não é um precursor da psicologia do trabalho, mas é um clínico que soube se ocupar com grande produtividade da atividade das crianças. Eu ia dizer do trabalho das crianças, mas não é isso, não devemos confundir tudo.

Ele chamou atenção para a questão da observação, porque ele praticava observação sobre as crianças, e ele se interrogou bastante acerca da observação. Ele se perguntava, o que é a observação? Vejamos o que ele disse. E, para mim, foi muito importante. Quando eu encontrei essa formulação de Wallon, eu compreendi um pouco melhor - e talvez um pouco menos mal - o que eu fazia.

A citação de Wallon é a seguinte, ele fala da observação que o clínico faz sobre a criança. Ele escreve: "A atenção que o sujeito" - a criança - "sente fixada sobre ele" - vejam, ele vai estudar a observação do ponto de vista do observado - "a atenção que o sujeito sente fixada sobre si parece, por uma espécie de contágio, muito elementar, obrigá-lo a se observar" - todos já fizeram essa experiência, quando nos sentimos observados, pouco a pouco, a gente se observa.

Vamos prosseguir com a afirmativa de Wallon: "Portanto, a observação de outrem parece obrigar o sujeito a se observar. Se ele está agindo, - esse sujeito, essa criança - o objeto de sua ação, e a ação ela mesma, são bruscamente suplantados pela intuição subjetiva que ele toma do seu personagem. É como uma inquietação, uma obsessão da atitude a adotar. É uma necessidade de se adaptar à presença de outrem, que se superpõe ao ato da execução". E Wallon diz que isso é um problema, porque quando a gente se sente observado, a gente perde o acesso aos nossos próprios meios para agir. Isso abre um problema imenso.

Isso quer dizer que quando fazemos observação em situação de trabalho, o resultado que se obtém é duplo. 
O primeiro resultado - que é muito importante, ao qual os ergonomistas aportaram uma grande quantidade de elementos - é que isso produz conhecimento sobre a atividade. Logicamente, quando se observa, se pode descrever a atividade de outrem.

Mas há um segundo resultado. A observação não produz conhecimento somente para o observador, produz também uma atividade no observado e produz, sobretudo, no observado um diálogo interior. Como disse Wallon, há um pouco de inquietação. Então o observado procura se apresentar da melhor forma possível, e representar aquilo que o outro quer ver. E isso provoca alguma coisa que não se vê, que é o diálogo interior do trabalhador, se observando no momento mesmo em que os outros o observam.

A clínica da atividade sistematizou essa observação, essa reflexão de Wallon. Todo o problema não se reduz simplesmente a utilizar os conhecimentos, sobre a atividade, que tiramos da observação. O problema fundamental é: o que fazemos da atividade do observado de observação de si mesmo. O que fazemos com isso? O que fazemos com esse diálogo interior que se expressa dessa forma: "Talvez eu não devesse fazer assim." Ou então "Quando ele observou meu colega, talvez meu colega tenha feito assim, tenha feito diferente" - essas são as discussões interiores que temos quando somos observados pelo Ergonomista, pelo psicólogo do trabalho. A gente se coloca perguntas - "Talvez quando eu volte amanhã eu faça de outra forma". Isso quer dizer que o observador e os trabalhadores observados se põem a pensar, a refletir sobre sua própria atividade e, então, tornam-se sujeitos da observação, não são mais simplesmente objetos da observação. O problema, em seguida, é: o que fazer desse diálogo interior?

Eu diria que, quando se inventaram os métodos dialógicos da análise do trabalho - de confrontação cruzada, instruções ao sósia e outros - pensamos muito nisso: dar um destino dialógico ao diálogo interior que se abre durante a observação. É isso que nos permite religar, a concepção de observação, que acabo de apresentar, à concepção da ação, que eu utilizei ao citar Tosquelles.

A primeira contribuição da clínica da atividade pode-se dizer que é uma reconceituação da questão da observação. Não é o contrário da ergonomia. Está em companheirismo com a ergonomia. Simplesmente é uma concepção psicológica da observação, que mostra que quando se observa, isso deixa traços junto ao observado. E o analista do trabalho vai se servir desses traços deixados junto ao observado para fazer a análise.

Então, um segundo ponto.

Esta observação, vocês podem notar, lembro que eu dizia de um lado a ergonomia, a observação; de outro, a psicopatologia do trabalho, a palavra. $\mathrm{Na}$ nossa herança há essa dupla filiação - a observação e a palavra, a palavra é a psicopatologia do trabalho. Simplesmente eu faço notar que, quando desenvolvemos a abordagem da observação, tal como acabo de fazer, a questão da palavra se coloca de outra forma, pois a observação que nós fazemos na clínica da atividade, de que eu acabo de falar, provoca a palavra interior. Portanto, em clínica da 
atividade a observação não é o contrário da palavra, é a fonte da palavra interior. Em seguida, dessa palavra interior, nós vamos fazer diálogos profissionais. Vocês podem ver que a observação se torna dialógica. Na clínica da atividade, diz-se naturalmente que a concepção da observação é dialógica. Portanto, a observação é um diálogo, portanto a palavra está dentro da observação.

Mas inversamente, quando realizamos autoconfrontações cruzadas, ou seja, quando confrontamos dois profissionais, ou melhor, quando coagimos dois profissionais a se comparar um ao outro, face a imagens "objetivas" da sua própria atividade, eles dialogam. Aqui estamos no domínio da palavra. Diríamos mesmo que estamos na intersubjetividade, aí estamos do lado da psicopatologia do trabalho.

Mas o que é que acontece? Quando os diálogos são difíceis, face à atividade que temos na tela, os profissionais entre eles se calam, porque eles não têm mais nada a dizer, eles se viram os dois em direção à tela e observam a situação de trabalho. Portanto, o diálogo em clínica da atividade é também um observatório. Portanto, vocês veem, a ideia é que a herança que é a nossa, psicopatologia do trabalho de um lado, ergonomia de outro, é a tentativa - que não é uma tentativa artificial, porque ela repousa sobre o problema da ação - de transformar a observação em diálogo de modo a tornar a palavra numa ferramenta de observação. Isso não é renunciar à observação, não é fazer menos observação, é fazer mais observação.

Da mesma maneira, do lado da palavra, do lado da escuta, é muito importante, e não há psicologia sem a função criadora da palavra do sujeito e dos sujeitos, é impossível imaginar a psicologia sem isso. Mas a palavra, na clínica da atividade, não é para escutar o vivido. A palavra é feita para agir, é um diálogo profissional para transformar a situação, e, portanto, é um diálogo para manter o vivido vivo. Não é um diálogo para apreender o vivido ou para conhecê-lo. É um diálogo para que o vivido se transforme, se desenvolva, na ação dialógica e na observação em curso do diálogo.

Portanto, é assim que, na clínica da atividade, fazemos a relação entre atividade e subjetividade. A atividade não é o contrário da subjetividade. A subjetividade eu a defino claramente - claramente para mim pelo menos, isso abre muitas questões já que é difícil de fato - como uma relação entre atividades. A subjetividade é uma atividade sobre a atividade. É a minha atividade ou a atividade de meu colega de trabalho como objeto de pensamento. É assim que se desenvolve a produção subjetiva de minha experiência. Portanto, não somos obrigados a escolher entre atividade e subjetividade. E, para terminar, eu diria que isso depende da conceituação que se faz da atividade. Essa seria minha conclusão.

Para concluir eu vou ainda me servir de Tosquelles. Tosquelles nos hospitais psiquiátricos, onde ele fazia a ergoterapia, evidentemente ele se interessava muito pela atividade real, ele olhava como faziam os loucos para trabalhar, quando eles trabalhavam. Ele produziu uma crítica, que faço minha, uma crítica da noção da atividade. Eu vou ler essa crítica: "Há um risco - escreve Tosquelles - de ver-se introduzir - observem a linguagem usada - atrás da linda palavra atividade uma distorção e um contrassenso muito grave. Não se pode confundir o conceito de atividade com a simples prestação de movimentos, com a presta- 
ção de esforços concordantes, com a simples aplicação e a simples resistência, submetidos aos desejos do mestre de escola ou do chefe de obras. Atividade quer dizer atividade própria. Poderia dizer se sentir ativo. Atividade que se enraíza nos sujeitos ativos que se desenvolve eventualmente no contexto social. A simples ocupação, não é sinônimo de atividade. Por exemplo, poderia se dizer que alguém que se agita, não é necessariamente ativo". Pode-se mexer muito, aparentemente há uma ação, mas ser absolutamente passivo. Pode-se estar agitado justamente porque não podemos nos sentir ativos na situação. Aí nos mexemos para nos defender da passividade.

Para Tosquelles, atividade não é simplesmente o que move. Podemos ter pessoas imóveis, como eu tenho aqui na minha frente, mesmo se começo a me alongar, pessoas imóveis, mas muito ativas - ao menos essa é a hipótese que estou fazendo sobre a atividade dos senhores. Não há uma atividade observável, há uma intensa atividade.

O que Tosquelles está dizendo é que devemos nos defender de uma concepção fetichista da atividade. A atividade não é simplesmente aquilo que se vê, não é o que se pode descrever, aquilo que se pode observar diretamente. Portanto, a atividade não é simplesmente a atividade realizada.

Em clínica da atividade estabelecemos, a partir daí, uma definição e uma distinção entre a atividade realizada e o real da atividade. A atividade realizada é o que se pode ver, se pode observar e se pode descrever.

Acontece que, como dizia Suzanne Pacaud, o homem se manifesta frequentemente pelo que ele faz, mas muitas vezes e sobretudo, diz ela, se manifesta por aquilo que ele não faz. A atividade é aquilo também que não se pode fazer, aquilo que não se faz, que gostaríamos de ter feito, é aquilo que guardamos no estômago, é a atividade (re)engolida, impossível, as atividades suspensas, as atividades impedidas. Não foi realizado, mas faz parte da atividade. E por isso que podemos dizer que a atividade realizada não tem o monopólio do real da atividade, o real da atividade é muito mais vasto que a atividade realizada. E, à maneira de Vigotsky, essa é quase a minha conclusão, "o homem é pleno a cada minuto de possibilidades não realizadas". E são essas possibilidades não realizadas que estão na fonte do desenvolvimento possível da atividade. E também, como diz Vigotsky, a atividade realizada é a atividade que venceu entre muitas outras atividades possíveis, a atividade que venceu é uma das possibilidades.

Resta buscar tudo que não foi realizado, mas que resta presente no que o sujeito continua a querer fazer, que é então a fonte do desenvolvimento.

Portanto, em clínica da atividade, colocando o problema dessa forma, tentamos trazer uma solução, entre outras. Ela é precária essa solução, ela é frágil, mas a disjunção que corre o risco de se instalar é a de nos fecharmos em, de um lado, uma análise do trabalho da atividade realizada e, de outro lado, em uma concepção de subjetividade, como negativa, como tudo que não foi realizado, como a atividade impedida, alienada, mas que, de certa forma, está separada, como é o caso em Le Guillant, da atividade realizada. De um lado, o risco de uma ativida- 
de sem subjetividade e, de outro, de uma subjetividade sem atividade. Podemos dizer que a clínica da atividade busca ultrapassar essa dificuldade. Eu não acho, pessoalmente, que ela tenha conseguido ultrapassar completamente essa dificuldade, mas é nesse caminho que ela avança, não sem alguma dificuldade.

Muito obrigado.

\section{O DEBATE}

\section{Helder Muniz: ${ }^{9}$}

A psicologia do trabalho tem uma tradição de intervenção em empresas em situações de trabalho, seja no setor privado, seja no setor público, não é, mas com as transformações do trabalho nós temos hoje também, com o problema do desemprego e um aumento do mercado informal de trabalho, situações de trabalho novas, fora das empresas, fora dessas situações de trabalho assalariado. Eu queria perguntar se já há experiências de estudos, desse ponto de vista da atividade, com pessoas que estão atuando fora desse mercado formal, com iniciativas econômicas novas; e se podemos pensar uma contribuição da psicologia do trabalho para essas situações fora do assalariamento tradicional.

\section{Y. C.:}

Eu estou verdadeiramente de acordo em considerar que o trabalho assalariado clássico vê a sua parte muito diminuída. Nós temos na França, particularmente na França, mas eu acho também no Brasil, uma situação em que a precariedade se desenvolveu consideravelmente, em que o desemprego tornou-se não somente uma situação transitória, mas uma condição social, durável, e a precariedade também. Nós sabemos muito bem que podemos levar a vida inteira passando de um trabalho a outro sem nunca poder antecipar o que vai acontecer de fato. Esses processos de desagregação social são extremamente importantes, há alguns estudos que foram conduzidos e, pessoalmente, eu trabalhei sobre essa questão uma vez, há alguns anos. Eu quero dizer um pouco de como, na época, abordamos a questão. Um primeiro ponto é que trabalhamos com pessoas que estavam fora do ambiente de trabalho desde muito tempo, em desemprego de longa duração, que talvez já tivessem perdido a esperança de reencontrar um posto de trabalho. Pudemos identificar aí (com um método que depois falaremos) uma psicopatologia do trabalho muito específica, o que chamamos de uma psicopatologia do trabalho do homem supérfluo, quer dizer, dos que, naquela situação, perderam o sentimento de serem úteis no mundo. O que é extremamente interessante é que o que tornava doentes esses desempregados não era somente não ter salário, não ter emprego, não ter dinheiro. Lógico que tudo isso era terrível, mas o que os tornava doentes era não poder trazer uma contribuição à história social, estarem sobrando, serem supérfluos. Havia o que podemos chamar uma psicopatologia do não trabalho (desouevrement), no sentido forte, de colocados fora da obra comum,

\footnotetext{
${ }^{9}$ Doutor em Engenharia de Produção pela Universidade Federal do Rio de Janeiro (2000) e pós-doutorado pela Universidade do Estado do Rio de Janeiro (2009). Atualmente é Professor Associado I da Universidade Federal Fluminense.
} 
interditados de contribuir à história humana. Eu penso que essa psicopatologia do desemprego é extremamente grave porque ela toca o ser, fundamentalmente. E me lembro também de um trabalho que fazíamos justamente com esse grupo de desempregados, no qual um deles falou um dia "passamos nosso tempo a ruminar e a pensar em tudo aquilo que não podemos mais fazer". Eu não vou desenvolver as ligações com a clínica da atividade, mas vocês vejam bem que a atividade do desempregado é muito intensa, a ruminação permanente, sentindo-se a mais, como alguém que não pode mais servir para nada, e não ter outra solução senão pensar aquilo que já fez e que não faz mais. O real da atividade nessa situação é muito cansativo, é perfeitamente compreensível que a saúde desses desempregados se degrade, porque sua fadiga é intensa. Não fazer nada, quando se está desempregado, é extremamente cansativo. Constatamos a deterioração da saúde mental e física dos desempregados que se deve à atividade impedida, à atividade contrariada, interdita, vejam o paradoxo. E, para mim, do ponto de vista clínico, é uma confirmação das hipóteses que nós fazemos em matéria de concepção da atividade. Nós trabalhamos, eu vou falar um pouco sobre o método, em vez de trabalhar primeiramente com os desempregados em geral, nós decidimos trabalhar com associações de desempregados. Na França se criaram essas associações durante certo tempo, agora elas são muito fracas, o que tornou difícil a minha cooperação com eles. Criou-se um movimento de luta nas associações de desempregados contra a precariedade, com sindicatos, associações, reagrupamentos de desempregados, que agiam nas ruas contra a precariedade, para encontrar um emprego, para acessar o trabalho, e não simplesmente ao trabalho como salário, mas como contribuição à história coletiva. E, então, nós trabalhamos um pouco na perspectiva da clínica da atividade, escolhemos trabalhar com pessoas em ação. Lógico, nem todos os desempregados fazem isso, mas na França nessa época havia um movimento social real de desempregados, que, de certa forma, tinha decidido tomar a sua sorte em suas próprias mãos. Nós estudamos justamente, junto com esses desempregados e as associações de desempregados, como desenvolver a sua ação. E eu penso que é precisamente porque tínhamos pessoas que transformavam a sua situação em ação que pudemos compreender alguma coisa sobre psicopatologia do desemprego, e sobre a atividade diminuída que evoquei ainda pouco, porque para chegar a dizer coisas assim, a se dizer coisas assim e compartilhá-las, é necessário já ter levantado a cabeça, é necessário desde já ter uma situação em que se renunciou à passividade e se tenta transformar essa passividade em ação. Dizer essas coisas, de uma intimidade incrível, "Eu estou cansado de nada fazer", como isso é difícil de dizer; se vocês dizem isso assim, a primeira vez nos faz rir, mas isso é profundamente verdadeiro. É profundamente perigoso não fazer nada, não poder participar do trabalho coletivo e da história comum. Acho que conseguimos traçar um caminho até essa intimidade subjetiva e mental dos desempregados, porque trabalhamos com desempregados que agiam contra o desemprego, que no fundo não faziam do desemprego um drama pessoal, mas que lutavam contra o desemprego, o qual era percebido como injustiça. É na ação contra a injustiça que chegamos a nos autorizar a dizer as coisas mais 
íntimas. Portanto, tínhamos tentado na época - hoje é mais difícil porque essas associações perderam terreno - tentamos na época compreender o desemprego com aqueles que já o haviam transformado em ação.

\section{Pierre Trinquet: ${ }^{10}$}

Antes de fazer a pergunta, quero fazer uma declaração preliminar, do quanto a ergologia tem uma forte dívida com relação aos trabalhos de Yves Clot. Porque a ergologia tem como pretensão ser pluridisciplinar e os trabalhos que são feitos nas disciplinas, em particular nas disciplinas que dirige Yves Clot, nos servem enormemente, e aproveito esta ocasião para agradecer publicamente.

A minha pergunta: como você bem sabe nesse momento na França temos um problema que me preocupa muito no campo do trabalho: são os suicídios nos locais de trabalho. É algo novo, que se desenvolve de uma forma bem dramática e preocupante. A questão é: Qual a reação de Yves Clot, em particular, e da escola que ele dirige, em relação a esse novo e preocupante fenômeno, ou seja, os fenômenos do suicídio nos locais de trabalho?

\section{Y. C.:}

Não é minha especialidade, como você bem sabe. Cristophe Dejours é um tanto especializado nessa questão, seria interessante ter o ponto de vista dele. Mas, de toda forma, eu vou dar o meu ponto de vista. Primeiramente, há uma primeira observação. Penso que insistimos num tipo de contágio do suicídio no trabalho, quer dizer paradoxalmente, a midiatização de que os suicídios são objeto, é algo que faz desaparecer as barreiras daqueles que se preservavam ainda de se suicidarem. Penso que aqueles que pensam atualmente em se suicidar em situação profissional são muito mais numerosos que aqueles que o cometem de fato, muito mais numerosos. Acho que o problema é extremamente grave. A tentação ao suicídio, poderíamos dizer, está muito disseminada no meio profissional, ao menos na França. A tentação ao suicídio é muito maior do que a tentativa de suicídio. Então acho que é necessário tomar mais a sério esse processo, o círculo dos potenciais suicidas é muito maior do que aqueles que passam ao ato de certa maneira. E a midiatização, legítima, que se constrói em torno dessas questões é contagiosa no sentido de que certo número de mulheres e sobretudo de homens - eu chamo atenção que, entre os suicídios no trabalho, a proporção de homens é considerável, 90\% são de homens, as mulheres se suicidam menos. Podemos considerar que a midiatização que se desenvolve sobre essas questões é, paradoxalmente, um acelerador do suicídio no trabalho. Por quê? Porque os que tinham a tentação de fazê-lo, avaliam a medida do impacto social do seu ato, e, assim, podem ser levados a considerar que vale a pena fazê-lo, porque vai tornar mais pesada a balança para que enfim as pessoas abram os olhos. Portanto, esse é o primeiro paradoxo ao qual eu me refiro: isso é dramático, o barulho que se faz hoje em torno dos suicídios, em minha opinião, é um acelerador dos suicídios. Não digo que devamos nos calar a respeito disso, mas eu penso que a responsa-

\footnotetext{
${ }^{10}$ Professor e doutor em Sociologia da Université de la Méditerranée e da Université de Provence.
} 
bilidade das mídias na manipulação desse problema é extremamente importante. Não somente das mídias, mas dos responsáveis políticos e sindicais. O problema é muito importante, eu considero que isso deva ser dito publicamente, que se deve dizer publicamente que é necessário tomar cuidado. Não é porque há muitos suicídios que devamos nos suicidar, é necessário dizer a verdade, o problema deve ser colocado dessa forma. Isso em primeiro lugar. Em segundo lugar, o conhecimento que temos hoje dos percursos dos que se suicidam, das histórias pessoais daqueles que chegam a esse ato dramático, são percursos que são bem tristemente interessantes, significativos. Significativos daquilo que compreendemos ao curso desses vários anos. Essas pessoas não são qualquer um. Em 80\% dos casos, são pessoas que se suicidam porque são apaixonadas pelo trabalho, são pessoas que não aceitam que maltratem a sua atividade profissional, não são pessoas que estão afastadas do trabalho, são pessoas que estão muito próximas do trabalho, que não aceitam mais que seu trabalho seja maltratado. Portanto, no fundo, os suicidas do trabalho, de certa forma, são pessoas que não transigem mais com a atividade profissional, não suportam mais que sua atividade profissional seja tratada como ela é tratada em muitas situações. Dito de outra forma, não são sujeitos desinvestidos, são pessoas sobreinvestidas, poderíamos talvez dizer investidas demais, que, no fundo, não chegam a instalar entre eles e sua atividade profissional a distância que permitiria encontrar outros meios de resistir à situação que está posta. Terceira observação, essa distância e seus recursos entre eles e a sua situação concreta é o buraco do coletivo do trabalho, o drama da falência do coletivo como instrumento de resistência à descompensação individual, à solidão simplesmente. Sabemos muito bem que o suicídio no trabalho se produz na conjunção de dois fenômenos. Primeiramente, as paixões destruídas no trabalho, a intolerância e a impossibilidade de continuar a suportar o insuportável, de suportar não se reconhecer naquilo que faz, principalmente isso: sair do trabalho no fim do dia dizendo a si mesmo "a gente não se pode olhar no espelho tendo feito aquilo que foi feito, que não é aquilo que se deveria fazer, aquilo que fomos obrigados a fazer não é aquilo que deveríamos fazer, nosso trabalho não é esse". Primeiramente, a conjunção disso, poderíamos dizer, da atividade contrariada e da falência do coletivo é que faz com que, nessa situação, não se tenha recursos para trabalhar com os colegas. Não há ao menos uma situação em que se possa constituir pelo coletivo um distanciamento para proteger um assalariado da descompensação, de sua própria vontade de desaparecer. Eu penso que, se juntamos o trabalho no qual cada um não pode mais se reconhecer com a falência dos coletivos, temos todos os ingredientes para que muitos assalariados cheguem a essa situação. Quando não podemos mais mobilizar, na nossa existência pessoal, outros recursos para introduzir essa distância, não há mais coletivo (de trabalho) e também não há mais nada. Há uma vida familiar desestruturada, uma conjuntura na qual nada mais nos sustenta. E, nesse momento, a solidão do trabalho vem ecoar com a solidão da vida pessoal, e nessa espécie de choque entre solidões pessoais e profissionais, a passagem ao ato se produz. Muitos assalariados suportam hoje situações profissionais de maltrato graças àquilo que eles são ainda como pessoas fora do ambiente de trabalho, no âmbito da família, com seus filhos, é lá que ele encontra os meios de resistir, ou eventualmente com colegas, nos círculos de amizade. É, muitas 
vezes, o que os impede de ir até o final. Para alguns sujeitos, a conjunção das duas situações, profissional e pessoal, os precipita em um túnel onde não se vê outra solução, para continuar a viver. Eu penso que temos a responsabilidade, nós como psicólogos, que estudamos a psicopatologia do trabalho, de mostrar até que ponto podemos nos matar no trabalho. E em algumas situações de análise de desempregados, que já são reconhecidas como doença profissional, como no trabalho de Le Guillant, é muito importante reconhecer essa situação como doença profissional, para certos sujeitos que jogaram todas as suas fichas no trabalho, porque as coisas já não iam bem na família, se o trabalho se desarranja ele não suporta.

\section{Marcelo Figueiredo: ${ }^{11}$}

Vou trazer uma discussão que já tivemos na sexta-feira com Pierre Trinquet, sobre essa questão dos suicídios. Eu não queria ficar nos suicídios, mas pensar a postura que a empresa adotou inicialmente... Eu não conheço os desdobramentos mais recentes. As notícias que chegaram ao Brasil, em se tratando dos suicídios na Renault - foram 3 suicídios em 5 meses - é que eles investiriam na formação dos gerentes em gestão do estresse, mas não aceitavam, isso dito pelo gerente maior da empresa chamado Carlos Gosnik, que é até conhecido de algumas empresas aqui no Brasil, que não aceitavam de modo algum rever as metas de produção. Considerando toda a tradição que o professor apresentou aqui, eu pergunto: Esse tipo de postura inflexível, em que as metas têm quase que um caráter sacrossanto, denota apenas uma miopia gerencial - uma explicação mais direta, mais simples - ou por trás desse tipo de postura tem algo que é deliberado e que, na verdade, não se explicaria apenas como uma mera miopia, um desconhecimento das potencialidades de determinadas intervenções que podem se mostrar eficazes nos marcos de uma concorrência acirrada como essa que a gente vivencia, melhor, presencia, hoje, no cenário capitalista da dita pós-modernidade?

\section{Y. C.:}

É uma questão difícil. Não tenho certeza de ter a resposta, francamente não tenho certeza de ter a resposta. Seria necessário fazer a clínica da atividade do Carlos. Mas, de toda forma, não é um problema pessoal, porque não há somente suicídios na Renault, mas também na Peugeot, em que não é o Carlos que dirige, em outras empresas também... Meu ponto de vista, que é, com certeza, um ponto de vista a discutir, é que não é simplesmente uma miopia; eu penso que os dirigentes de empresa sabem muito bem o que se passa, eles são muito lúcidos sobre essa situação. Eu acredito que, portanto, eles escolheram prosseguir nessa via porque não há alternativa, para eles, do ponto de vista dos objetivos, que são os deles, isso quer dizer do ponto de vista do desenvolvimento da rentabilidade dessas grandes empresas. No fundo, eles fazem certo tipo de cálculo. Já aconteceu de eu falar diretamente com Carlos e outros gestores. Há uma posição um pouco cínica. Eles dizem: "é verdade que a corrida louca na qual nós nos engajamos é um problema, ela provoca até suicídios, mas se nós abandonamos essa corrida malu-

\footnotetext{
${ }^{11}$ Doutor em Engenharia de Produção pela Universidade Federal do Rio de Janeiro. Atualmente é
} professor adjunto IV da Universidade Federal Fluminense. 
ca, é a empresa inteira que está condenada e as consequências sociais são ainda mais graves do que aquelas que nós conhecemos". Dito de outra forma, vocês podem ver que essa argumentação consiste em dizer que não se faz omelete sem quebrar ovos, e em seguida pode-se fechar os olhos sobre essas situações. Mas não consiste apenas em fechar os olhos, porque essas empresas estão quase... , sobretudo se elas começam a ser condenadas, se os suicídios começam a ser reconhecidos como acidentes profissionais, penso que elas vão construir uma reação, uma resposta a esse gênero de situação. Elas estão começando a construir essa reação, é interessante ver como elas tratam essa questão. Em particular, na Renault o que se implementou foi algo em torno da gestão dos recursos humanos, foi um dispositivo de gestão do estresse, como você acaba de dizer. Isso quer dizer que a ideia central é que é preciso acrescentar, sobrepor à gestão da empresa, tal qual ela está, uma nova gestão, que é a gestão do estresse. E necessário considerar que o estresse é um objeto de gestão como outro, portanto, é necessário implementar serviços mediante os quais vamos ajudar cada um dos sujeitos a suportar o que é insuportável. Portanto, dito de outra forma, vamos operar o que podemos chamar uma transfusão psicológica. Quer dizer "Você está em dificuldade, você é que é frágil. É verdade que a situação é difícil, mas você é que é frágil, porque não é todo mundo que se suicida. Se você está tentado pelo suicídio, é que há uma fragilidade pessoal em você". Aí há duas soluções "Ou houve um engano ao the contratar, um erro de recrutamento, é necessário verificar quando se recruta, tem que se tomar cuidado com isso; e já que você está aqui e a gente não pode te desempregar, a empresa pode te ajudar, ela vai colocar à sua disposição um serviço de escuta no qual você pode liberar todas as suas inquietações, sua depressão e com psicólogos formados para isso, vamos lhe ajudar a ultrapassar a dificuldade em que você está, favorecendo em você a construção de novos recursos pessoais". Vocês veem, há um problema. O problema é que, nesse momento, há um novo sistema produtivo, e penso que há um modelo que está em forte desenvolvimento que devem fazer refletir ao mesmo tempo os gestores e os psicólogos. Por um lado, há uma loucura produtiva, uma busca pela produtividade desenfreada, um tipo de neofordismo que se desenvolve, com o desenvolvimento muito forte das prescrições, mesmo na matéria de segurança, mesmo de higiene do trabalho. De um lado, aumenta-se a pressão, porque se pensa que não há outra solução. De outro lado, vê-se muito bem, e eu penso que há muita lucidez do ponto de vista das grandes empresas, vê-se bem que há alguma coisa de insuportável nesse sistema, os gerentes de alto nível não são cegos para essa situação. Eles concluem que é necessário desenvolver o que eu chamaria de um travesseiro de compaixão, dispositivos de gestão do sofrimento. Eu diria que o sistema produtivo que se configura é um neofordismo montado sobre travesseiros de compaixão, como amortecedores psicológicos do sofrimento que acreditamos inelutáveis nesse sistema. Vemos que há um problema maior para a psicologia do trabalho, porque muitos clínicos do trabalho, e é por isso que eu falava que tinha medo do futuro da clínica do trabalho, porque muitos clínicos do trabalho consideram que é normal, faz parte do seu trabalho ajudar as pessoas a aceitar essas situações insuportáveis. Há empregos, em particular na França, para psicólogos clínicos encarregados de ajudar os sujeitos a usar cada vez mais seus recursos pessoais, sem tocar na situa- 
ção que deteriora a saúde. Há, então, o verdadeiro problema de uma psicologia do trabalho compassional, uma psicologia que escuta o sofrimento, que recupera o vivido, para reciclar o vivido pelo sujeito; não para manter viva essa experiência para transformar a situação profissional. Então eu diria que a clínica do trabalho que nós tentamos fazer, em particular no CNAM, ela está confrontada com esse problema. E nossos estudantes, acontece com eles de encontrarem emprego, e não é fácil encontrar trabalho, em novas oficinas, em sociedades de serviços que estão se desenvolvendo, por exemplo, a Agência para Emprego, ANPE (Agence Nationale pour l'Emploi) - que é a grande agência para o emprego na França - ela acaba de criar um serviço interno na empresa que se chama "Minha Linha de Escuta", 24 horas por dia. Há psicólogos clínicos, formados em psicanálise, que estão atrás dos telefones, dia e noite, e os assalariados da empresa podem chamá-los dia e noite para tratar de problemas pessoais ou profissionais, sem distinção. E a empresa indica na sua gestão de recursos humanos que ela criou esse novo serviço gratuito para ajudar os assalariados a resolverem seu problema pessoal, o que é uma providência com características de filantropia social. Vejam, a empresa é moderna e cuidadosa, não somente se ocupa da questão, mas ainda por cima, gratuitamente, ela cria serviços para ajudar os empregados a resolver seus problemas psicológicos, pessoais e profissionais. Vejam bem a perversidade social desse sistema que faz com que, de um lado, a empresa alimente a descompensação psíquica no trabalho e, de outro lado, ela faça dessa situação objeto de gestão, pedindo aos psicólogos clínicos que dêem suporte a essa iniciativa. A minha conclusão é muito simples, eu penso que logo teremos estudos e pesquisas de psicopatologia do trabalho a fazer junto a esses psicólogos clínicos, porque o que eles fazem ao telefone, 24 horas por dia, nesses quadros clínicos tortos, isso não é trabalho de psicólogo, isso vai deixá-los doentes.

Recebido em: fevereiro de 2010

Aceito em: abril de 2010 
